\title{
Control of solid oxide fuel cell ceramic interfaces via atomic layer deposition
}

\author{
Jongsu Seo ${ }^{1}$, WooChul Jung ${ }^{1}$, Jeong Hwan Kim ${ }^{2 \dagger}$
}

${ }^{1}$ Dept. Materials Science and Engineering, Korea Advanced Institute of Science and Technology (KAIST), Daejeon, 34141, Republic of Korea

${ }^{2}$ Department of Advanced Materials Engineering, Hanbat National University, Daejeon, 34158, Republic of Korea

\section{원자층 증착법을 통한 고체산화물 연료전지의 세라믹 인터페이스 제어}

\author{
서종수 ${ }^{1}$, 정우철 $^{1}$, 김정환 $^{2 \dagger}$ \\ 1한국과학기술원(KAIST) 신소재공학과 \\ 국립한밭대학교 신소재공학과
}

(Received May 20, 2020; Accepted June 2, 2020)

\begin{abstract}
Solid oxide fuel cell (SOFC) have attracted much attention due to clean, efficient and environmentalfriendly generation of electricity for next-generation energy conversion devices. Recently, many studies have been reported on improving the performance of SOFC electrodes and electrolytes by applying atomic layer deposition (ALD) process, which has advantages of excellent film quality and conformality, and precise control of film thickness by utilizing its unique self-limiting surface reaction. ALD process with these advantages has been shown to provide functional ceramic interfaces for SOFC electrodes and electrolytes. In this article, recent examples of successful functionalization and stabilization on SOFC electrodes and electrolytes by the application of ALD process for realizing high performance SOFC cells are reported.
\end{abstract}

Keywords: solid oxide fuel cell (SOFC), atomic layer deposition(ALD), ceramic interface, functionalization, 3-D nanostructure

${ }^{\dagger}$ Corresponding Author: Jeong Hwan Kim

E-mail: jkim@hanbat.ac.kr 


\section{Introduction}

에너지 수요 증가 및 환경 문제로 인해 고효율을 지니 며 친환경적인 발전 기술에 대한 필요성이 점점 중요해 지고 있다. 이러한 요구를 충족시키는 다양한 에너지 생 산 기술 중에서, 고체산화물 연료전지 (solid oxide fuel cell, $\mathrm{SOFC}$ )는 높은 에너지 효율과 다른 연료전지와는 다르게 다양한 연료를 주입하여 구동할 수 있다는 장점 으로 인해 차세대 발전 장치로 크게 주목받고 있다.

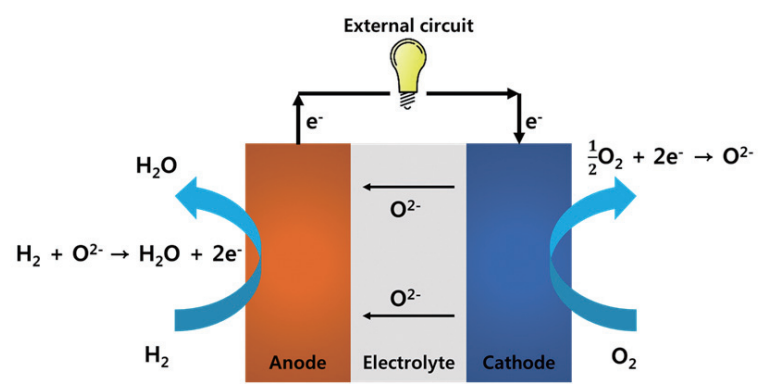

Fig. 1. 연료전지 모식도.

연료전지란 화학 에너지를 다른 중간 과정 없이 전기 화학 반응을 통해서 바로 전기 에너지로 변환하는 장치 로써, 연료극 (anode), 공기극 (cathode) 그리고 전해질 (electrolyte)로 구성되어있다 (Fig. 1). 이 중, 전해질이 고체 산화물로 이루어진 경우를 $\mathrm{SOFC}$ 라고 하는데, 고 체 산화물의 충분한 산소 이온 전도도를 위해서 $\mathrm{SOFC}$ 는 일반적으로 $600{ }^{\circ} \mathrm{C}$ 이상의 고온에서 작동하게 된다. 이러한 높은 작동온도는 $\mathrm{SOFC}$ 구동에 기술적 어려움을 야기하기도 하지만, 동시에 탄화수소 연료의 열분해 반 응을 촉진하며, 따라서 $\mathrm{SOFC}$ 는 다른 연료전지와는 다 르게 수소 연료 이외에도 다양한 연료를 직접 주입하여 구동할 수 있는 장점이 있다. $\mathrm{SOFC}$ 구동 시 각 전극에 서 일어나는 반응으로는 다음과 같다.

cathode에서 일어나는 반응;

$1 / 2 \mathrm{O}_{2}+2 \mathrm{e}^{-} \rightarrow \mathrm{O}^{2-}$ anode에서 일어나는 반응;

$\mathrm{H}_{2}+\mathrm{O}^{2-} \rightarrow \mathrm{H}_{2} \mathrm{O}+2 \mathrm{e}^{-}$

(anode에서 사용되는 산소 이온은, cathode에서 전 해질을 통과하여 공급된다.)

고성능의 $\mathrm{SOFC}$ 를 구현하기 위해서는 고활성의 전극 소재 선별 및 추가적인 촉매 도입을 통해 전극에서 일어 나는 반응을 촉진시키거나, 이온 및 전자 전도성이 뛰어 난 소재를 사용하여 ohmic loss를 최소화시켜야 한다. 또한, $\mathrm{SOFC}$ 는 고온에서 작동하는 장치이기 때문에 필 연적으로 고온에서의 다양한 열적/화학적 열화가 발생 하게 되는데, 이를 억제하는 다양한 연구들도 활발히 진 행되고 있다.

본 리뷰에서는, 고성능의 $\mathrm{SOFC}$ 구현을 위해 보고 된 다양한 연구들 중, 원자층 증착법 (atomic layer deposition, $\mathrm{ALD})$ 을 $\mathrm{SOFC}$ 의 전극 및 전해질 성능과 내 구성 향상에 활용한 최근 사례들을 소개한다. $\mathrm{ALD}$ 는 매 우 얇고 치밀한 박막을 코팅할 수 있는 기술로 다른 코 팅기술과 비교했을 때 매우 우수한 단차피복성 (stepcoverage)를 보여 복잡한 다공성 구조체 표면에도 균일 하게 코팅이 가능하다는 장점을 가지고 있다. 아직까지 $\mathrm{ALD}$ 는 $\mathrm{SOFC}$ 셀이나 스텍 제작 과정에 활발히 사용되 고 있지는 않지만, 최근 세라믹 소재들로 구성된 $\mathrm{SOFC}$ 전극과 전해질에 새로운 기능성 계면을 만들어 낼 수 있 음이 활발히 보고되고 있다. 본 리뷰에서는 이러한 장점 을 지닌 $\mathrm{ALD}$ 의 도입이 $\mathrm{SOFC}$ 분야에 어떠한 기여를 하 였는지를 구체적으로 살펴보겠다.

\section{Overview of atomic layer deposition}

ALD 기술은 반도체 분야에서 트랜지스터의 고유전 율 게이트 유전막 (high-k gate dielectrics) 부문과 DRAM 캐패시터의 유전막 (dielectric film) 부문을 중 심으로 오랜 시간 개발되어 왔으며, 특유의 자기 제한적 표면 반응 (self-limiting surface reaction)에 기인해 $\mathrm{ALD}$ 박막은 $\AA$ 수준의 두께 정확도와 우수한 단차피복 성을 보여 준다 ${ }^{1,2)}$. 최근에는 디스플레이 분야의 봉지막 

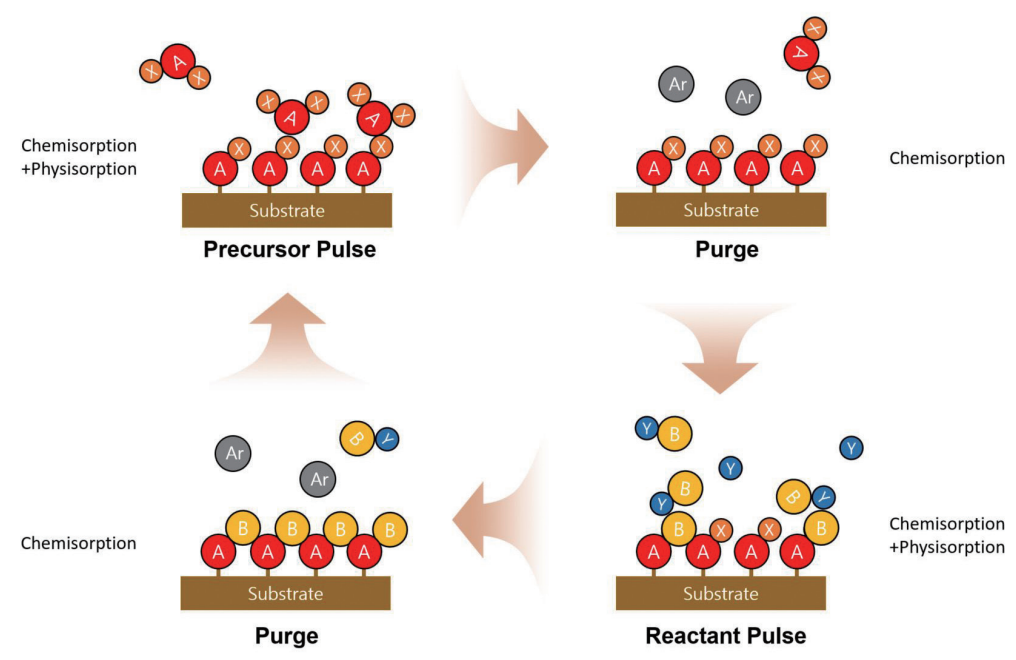

Fig. 2. ALD cycle의 표면 반응 메커니즘

(encapsulation layer) 뿐만 아니라 연료전지, 태양전 지, 배터리 등 에너지 소재 제작에도 널리 활용되고 있 다. ${ }^{3)-5)}$

$\mathrm{ALD}$ 박막 공정은 화학기상증착법 (chemical vapor deposition, CVD)과 달리 반응 원료를 각각 분리하여 공급하여, 한 사이클 증착 시에 자기 제한적 표면 반응 에 의해 단원자층 (monolayer) 이하의 박막이 성장하 게 한다. ${ }^{6}$ Fig. 2는 전구체 AXn과 반응제 $\mathrm{BYm}$ 의 두 가지 원료를 이용하여 $\mathrm{AB}$ layer를 증착하는 $\mathrm{ALD}$ 사 이클을 간략히 나타낸 것이다. ALD 공정에서의 반응 은 Fig. 2에서 보는 바와 같이 전구체 주입 (precursor pulse)-퍼지 (purge)-반응제 주입 (reactant pulse)퍼지 (purge)의 4단계로 이루어진다. 먼저 전구체 주입 단계에서는 $\mathrm{AXn}$ (일반적으로 유기 금속 전구체)을 공급 하여 $\mathrm{A}$ 원소가 기판 위에 흡착하게 된다. 이때, 기판의 작용기 (functional group, 보통 - $\mathrm{OH}$ 기)와 결합한 $\mathrm{A}$ 원소는 기판과 화학흡착으로 강한 결합을 하고 있다. 반 면에 $\mathrm{AXn}$ 분자끼리의 흡착은 물리흡착으로 이루어져 결 합력이 약하기 때문에 쉽게 떨어질 수 있으며, 따라서 그 다음 단계인 퍼지 단계에서는 물리흡착한 $\mathrm{AXn}$ 분자 는 불활성 기체(Fig. 2에선 $\mathrm{Ar}$ )의 충돌에 의해 떨어져 나가 제거된다. 즉, 화학흡착과 물리흡착의 결합력 차이 에 의해 $\mathrm{ALD}$ 에서는 원자층 단위의 박막 형성이 가능하
게 된다. 이후에 $\mathrm{AB}$ 화합물을 만들기 위해 반응제 $\mathrm{BYm}$ 을 공급하게 되면, $\mathrm{BYm}$ 분자와 기판에 흡착되어 있는 $\mathrm{A}$ 원소가 서로 화학 반응을 통해 $\mathrm{A}-\mathrm{B}$ 결합이 이루어지 게 된다. 이후에 퍼지 단계를 통해 물리흡착하고 있는 $\mathrm{BYm}$ 분자는 모두 제거되고, 결국 $\mathrm{AB}$ monolayer가 성 장된다. 이와 같은 과정이 한 ALD cycle로 구성되며, 증착속도(cycle당 증착 두께)는 ligand size에 의한 가림 (hinderance)으로 인해 보통 사이클당 monolayer 두께 이하로 나타난다. ${ }^{7)}$

이러한 Layer-by-Layer 메커니즘에 따른 증착 방식 을 나타내기 때문에 $\mathrm{ALD}$ 는 얇은 두께의 박막에서도 정 확한 두께 조절이 가능하다는 장점을 갖는다. 또한 자기 제한적 표면 반응에 의해 박막이 증착되기 때문에 3-D 고종횡비 나노 구조물에서도 우수한 단차피복성을 나타 내며, 또한 기상화학반응을 이용하지 않기 때문에 CVD 보다 상대적으로 낮은 온도의 공정이 가능하다는 장점 을 갖는다. ${ }^{8)-9)}$

\section{Reports using ALD in SOFC electrolytes}

고성능 $\mathrm{SOFC}$ 를 구현하기 위해서는 얇고 치밀한 전해 질 제작이 매우 중요하다. 전해질의 ohmic loss를 최소 화하고 gas leakage가 없는 치밀한 박막을 만들기 위 

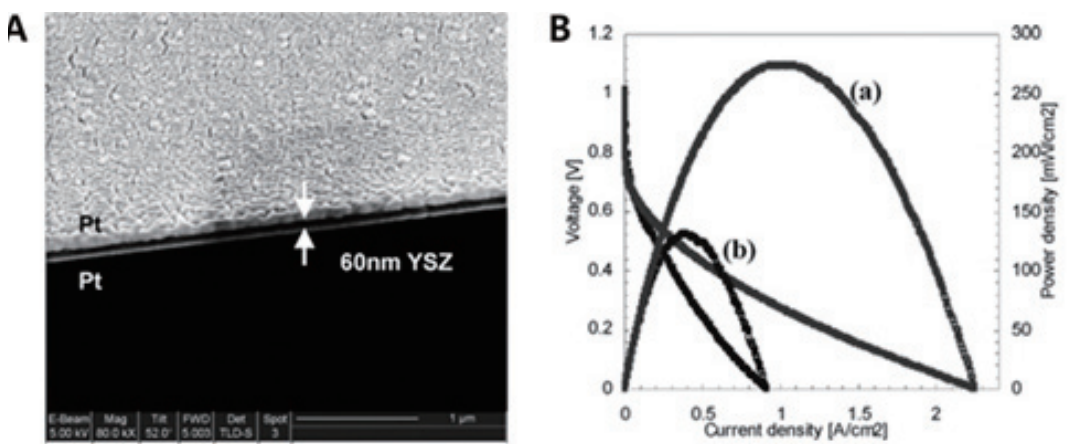

Fig. 3. (A) 백금 전극 사이에 ALD를 이용하여서 증착된 YSZ 전해질 SEM 사진. (B) (a) ALD를 이용하여 증착한 YSZ 전해질을 사용하였을 때와, (b) RF-sputtering을 이용하여 제작된 YSZ 전해질을 사용하였을 때의 $350{ }^{\circ} \mathrm{C}$ 에서의 전력 밀도. ${ }^{10}$

해 지금까지 다양한 공정들이 연구되고 있다. 일반적으 로 사용되는 sol-gel method 혹은 sputtering 기법으 로 제작된 전해질에 비해, $\mathrm{ALD}$ 를 이용하여 제작된 전 해질은 매우 얇은 두께에서도 gas leakage 없이 치밀한 구조를 확보할 수 있으며, 따라서 $\mathrm{SOFC}$ 의 전력밀도 향 상에 ALD가 기여할 수 있다. Fig. 3에 나오는 것처럼, Frinz B. Prinz 연구팀은 Yttria-stabilized zirconia (YSZ)를 $\mathrm{ALD}$ 를 이용하여 $\mathrm{SOFC}$ 전해질을 제작하여 그 특성을 보고하였다.

미세구조 분석 결과, 스퍼터로 제작된 백금 전극 사 이에 $\mathrm{ALD}$ 를 이용하여 제작된 YSZ 전해질이 치밀하 고 균일하게 증착이 된 것을 확인하였다. 또한, $\mathrm{RF}-$ sputtering을 이용하여 $50 \mathrm{~nm}$ 의 두께로 제작된 YSZ 전해질을 사용한 셀과, $\mathrm{ALD}$ 를 이용하여 제작된 전해 질을 사용한 셀의 전력밀도를 $350{ }^{\circ} \mathrm{C}$ 에서 비교한 결과, $\mathrm{ALD}$ 를 이용하여서 제작된 YSZ 전해질을 사용한 셀이 $\mathrm{RF}$-sputtering을 사용하여 제작된 전해질을 사용한 경 우보다 약 2 배의 전력밀도 향상이 확인되었다. 연구팀 은 이러한 성능 향상의 이유로 $\mathrm{ALD}$ 를 이용하여 제작한 전해질이 $\mathrm{RF}$-sputtering으로 제작된 전해질보다 이온 전도 특성이 소폭 우수하기 때문이라고 보고하였다. 뿐 만 아니라, $\mathrm{ALD}$ 로 증착된 YSZ 전해질은 bulk YSZ 대 비 나노 수준의 결정립계를 지니고 있으며, 나노 결정립 계에서의 뛰어난 산소 교환 반응 속도 역시 전극 반응성 을 크게 증가시키는데 기여한 것으로 판단하였다.

현재는 이 사례처럼 전해질 전체를 $\mathrm{ALD}$ 로 제작하는
것뿐만 아니라, 전해질의 ohimc resistance를 크게 증 가시키지 않는 선에서 전극과 전해질 사이에 매우 얇은 inter-layer를 삽입하여 전극과 전해질 계면 특성을 향 상시켜 $\mathrm{SOFC}$ 의 성능을 향상시키는 연구도 활발히 진 행되고 있다. Fritz B. Prinz 연구팀은 ALD Yttriadoped-ceria (YDC)를 YSZ와 전극 계면 사이에 증착하 였다 (Fig. 4). 그리고, Ce와 Y의 pulsing ratio를 다양 하게 바꾸어 가면서, 다양한 doping level의 YDC를 증 착하고, 다양한 조성의 $\mathrm{YDC}$ 가 전력 밀도에 미치는 효 과를 확인하였다. 그 결과, $350{ }^{\circ} \mathrm{C}$ 에서 $\mathrm{YDC}$ 가 코팅되 지 않은 셀의 성능 대비, $\mathrm{ALD}$ 를 이용하여 약 $12 \%$ 의 Y 가 도핑된 $\mathrm{YDC}$ 가 사용된 셀이 2 배 이상의 높은 성능 을 보이는 것이 확인되었다. 이는, inter-layer를 도입 하게 됨으로써 활성점이 $\mathrm{Pt} / \mathrm{YSZ} / \mathrm{O}_{2}$ 에서 $\mathrm{Pt} / \mathrm{YDC} / \mathrm{O}_{2}$ 로 바뀌게 되고, YSZ보다 YDC가 oxygen reduction reaction (ORR) 반응에 있어서 우수한 활성을 지녔기 때문으로 보고되었다. 또한, 특이한 점으로는 기존 문헌 들에서는 8-10\%의 $\mathrm{Y}$ 가 도핑된 $\mathrm{YDC}$ 가 최적의 산소 이 온 전도체라는 보고와는 달리, Pt-YSZ 전극에서는 약 $12 \%$ 의 $\mathrm{YDC}$ 가 가장 높은 성능을 보였다는 점에 있다. 본 연구팀에서 약 $12 \%$ 의 Y이 도핑된 $\mathrm{YDC}$ 에서 높은 성 능 향상을 보이는 이유로, $\mathrm{Y}$ 도핑으로 인해서 형성된 산 소 공극이 산소 흡착을 용이하게 되었고, 이렇게 향상 된 산소 흡착 거동으로 인해 전극과 전해질 계면 저항이 줄어들게 되어 우수한 성능 향상이 되었다고 주장하였 다. 반면, $\mathrm{Y}$ 농도가 너무 적을 때는 충분한 산소 공극이 


\section{특 집 ㅁㅃ 서종수, 정우철1, 김정환 ${ }^{2 \dagger}$}
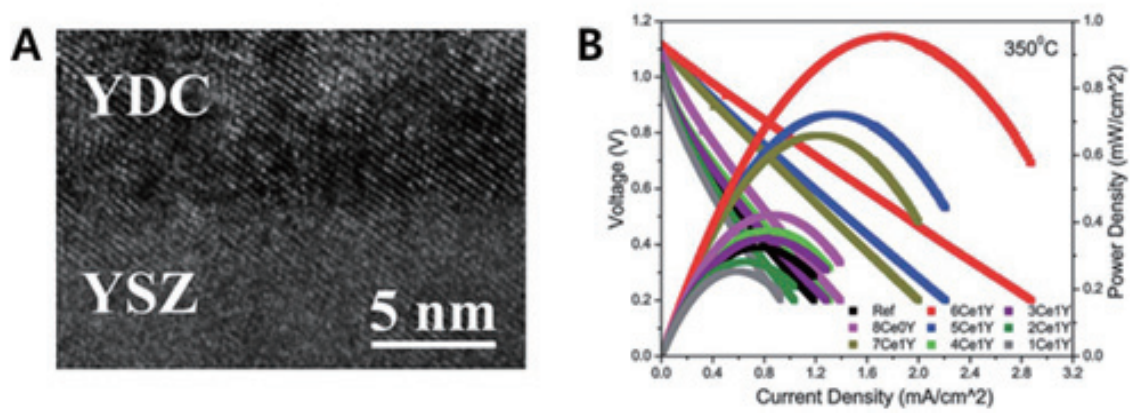

Fig. 4. (A) YSZ위에 ALD를 이용하여서 증착된 Yttria-doped-ceria (YDC)의 단면 TEM 사진. (B) $350{ }^{\circ} \mathrm{C}$ 에서의 다양한 조성의 YDC 증착 유무에 따른 전력 밀도."

형성되지 못하고, 너무 농도가 높을 때는 산소 공극의 agglomeration 현상으로 인해 성능이 감소하는 것이라 고 보고하였다. 이처럼, 본 연구는 inter-layer의 도입 을 통해 성공적인 성능 향상뿐만 아니라, $\mathrm{ALD}$ 를 이용하 여서 정밀한 조성 탐색을 통해 물질 최적화를 이루었다 는 점에서 의의가 있다.

\section{Reports using ALD in SOFC electrodes}

매우 얇고 치밀한 나노사이즈의 결정립계를 지니는 박막을 제공하는 장점 이외에도, $\mathrm{ALD}$ 는 우수한 단차피 복성으로 인해서, 복잡한 구조체를 균일하게 코팅할 수 있는 장비이다. 이러한 장점으로 인해서, $\mathrm{ALD}$ 는 복잡 한 3-D 구조를 지니는 $\mathrm{SOFC}$ 전극을 균일하게 코팅하 여, 표면이나 계면을 안정화 및 기능화 할 수 있다. 본 챕터에서는 $\mathrm{ALD}$ 코팅을 통해 고온에서 일어날 수 있 는 다양한 열적, 화학적 열화 현상을 개선한 사례와, 3 성분계 이상의 기능성 산화물을 코팅하거나 금속 촉매 를 도포하여 전극 표면을 기능화한 사례로 나누어 ALD 가 $\mathrm{SOFC}$ 전극에 기여한 연구 사례에 대해서 소개하도 록 하겠다.

\subsection{Thermal/chemical stabilization via ALD}

귀금속, 전이금속 계열의 $\mathrm{Pt}, \mathrm{Ag}, \mathrm{Ni}, \mathrm{Ru}$ 등의 금속 재료는 높은 전도도뿐만 아니라 cathode 쪽에서 일어나 는 oxygen reduction reaction이나, anode에서 일어나
는 fuel oxidation reaction에 있어서 우수한 촉매 특성 으로 인해서 $\mathrm{SOFC}$ 의 전극 소재로 많이 활용되고 있다. 하지만, $\mathrm{SOFC}$ 의 높은 작동온도로 인해서 고온에서 제 작된 전극이 뭉치게 되고, 이로 인해 전자 흐름이 끊기 거나, 전극의 비표면적 감소 및 핵심 반응사이트로 알려 진 삼상계면 (triple phase boundary, TPB) 감소로 인 한 비가역적인 성능 저하는 $\mathrm{SOFC}$ 의 장기 구동을 위해 서 해결해야 할 필수적인 문제이다. 이를 해결하기 위해 서, 우리 연구팀은 $\mathrm{ALD}$ 를 이용하여 sputtering으로 제 작된 다공성 $\mathrm{Pt}$ 전극을 $\mathrm{Al}_{2} \mathrm{O}_{3}$ 로 코팅하는 연구를 시도하 였다 (Fig. 5).

그 결과, Fig. 5 를 보면, 코팅이 되지 않은 백금 전극 의 경우 $500{ }^{\circ} \mathrm{C}$ 에서 10 시간만 노출되어도 미세구조가 뭉치는 것을 알 수 있었다. 반면에 $3.6 \mathrm{~nm}$ 의 $\mathrm{Al}_{2} \mathrm{O}_{3}$ 가 코 팅된 백금 전극의 경우는 초기 미세구조를 잘 유지한다. 하지만 더 두껍게 코팅된 $6 \mathrm{~nm}$ 의 경우에는 초기 미세구 조를 잘 유지하기는 하지만 절연체인 $\mathrm{Al}_{2} \mathrm{O}_{3}$ 가 너무 두껍 게 코팅되어, charging 문제로 인해 이미지가 선명하게 얻어지지 않는 것을 알 수 있었다. 이러한 미세구조가 미치는 영향을 임피던스 분석을 통해 측정한 결과, 450 ${ }^{\circ} \mathrm{C}$ 에서 $\mathrm{Al}_{2} \mathrm{O}_{3}$ 가 $3.6 \mathrm{~nm}$ 코팅된 백금 전극이 코팅이 되 지 않은 전극에 비해서 산소 환원 반응에 대한 전극 반 응성이 2 배 이상 향상되었음을 보였다. 하지만, 더 두꺼 운 $6 \mathrm{~nm}$ 의 $\mathrm{Al}_{2} \mathrm{O}_{3}$ 가 코팅이 된 백금 전극에서는 코팅이 되지 않은 전극 보다 약 2 배가량 큰 전극 저항을 나타내 었다. 결론적으로 적절한 $\mathrm{Al}_{2} \mathrm{O}_{3}$ 코팅을 하면, 고온에서 
A
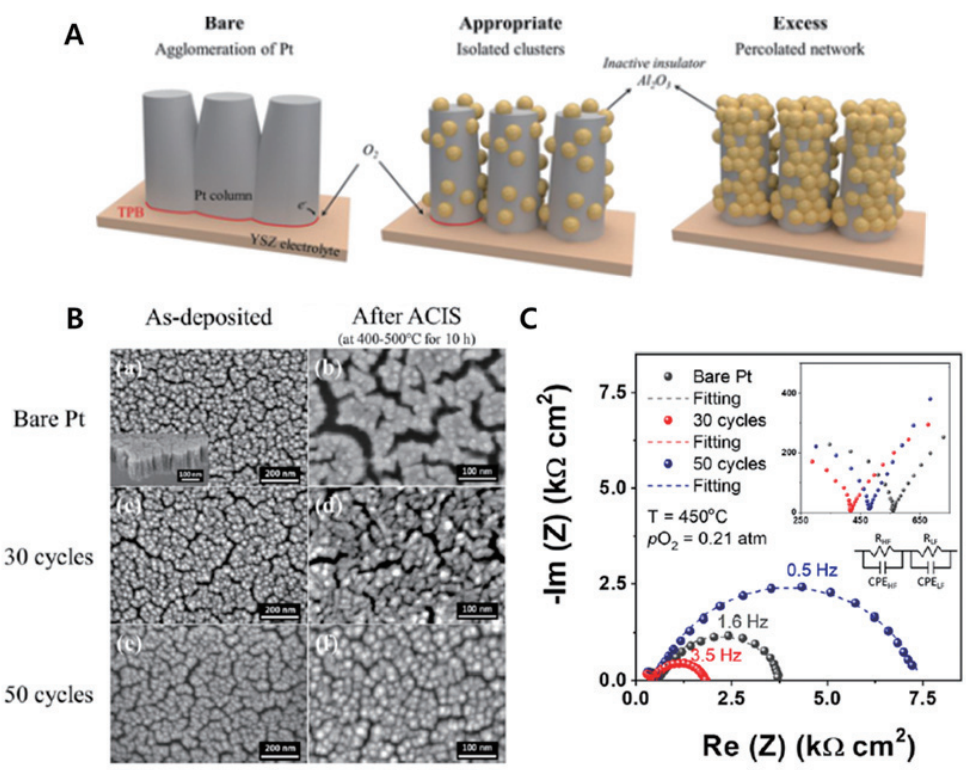

Fig. 5. (A) $\mathrm{Al}_{2} \mathrm{O}_{3}$ 코팅을 통한 $\mathrm{Pt}$ 전극의 triple phase boundary (TPB)를 안정화하는 모식도. (B) $\mathrm{Al}_{2} \mathrm{O}_{3}$ 코팅 유무에 따른 열처리 전/후의 백 금 전극 $\mathrm{SEM}$ 사진. (C) $\mathrm{Al}_{2} \mathrm{O}_{3}$ 코팅 유무에 따른 백금 전극의 임피던스 분석 결과. ${ }^{12}$

의 백금 뭉침 현상을 완화하여 산소 환원 반응의 활성점 으로 알려진 TPB 밀도를 높게 유지하는 것이 가능하며, 이에 따라 높은 성능이 구현될 수 있다. 반면, 너무 두껍 게 코팅을 하면 전자의 흐름을 방해하거나, nano-scale 의 gas channel을 막게 되어서 산소 공급이 원활하게 되지 않기 때문에 성능이 감소하게 된다.

이렇게 백금 전극의 열적 내구성 향상을 통한 반응 성 향상뿐만 아니라, 안지환 교수 연구팀은 $\mathrm{Ru}$ 전극 위 에, YSZ를 ALD로 코팅한 후, 연료극에서의 연료 산 화 반응에 대한 그 효과를 보고하였다. 본 연구에서는, sputtering으로 제작된 다공성의 $\mathrm{Ru}$ 전극 위를, $\mathrm{ALD}$ 를 이용하여 $10 \mathrm{~nm}, 20 \mathrm{~nm}, 40 \mathrm{~nm}$ 를 증착하고 methane 연료에 대한 전극 반응성 및 내구성을 확인하였다. Fig. 6 을 보면, 단면 TEM 분석을 통해, 전극 내부까지도 균 일하게 YSZ가 증착이 된 것을 확인하였다. 뿐만 아니 라, 고온에 노출된 ALD 박막 내부에는 micro-crack이 형성되는 것을 확인하여, 원활한 연료 공급이 되는 것과 동시에 TPB가 확장된다는 것을 확인하였다. 더 나아가, 이렇게 제작된 샘플들의 전력 밀도를 비교해보면, YSZ 가 코팅되지 않은 $\mathrm{Ru}$ 전극을 지닌 셀의 경우 초기 수 시
간 내에서 급격한 성능 저하를 보이는 반면, $10 \mathrm{~nm}$ 의 $\mathrm{YSZ}$ 가 코팅된 $\mathrm{Ru}$ 전극을 지닌 셀의 경우 초기 전력 밀 도가 $35 \%$ 증가하였고, 그 내구성 또한 매우 우수한 것 을 확인하였다. 본 연구팀은 $\mathrm{ALD}$ 를 이용한 전극 코팅 이, 전극의 열적 뭉침 효과를 완화하여 반응 활성점인 $\mathrm{TBP}$ 밀도를 높게 유지하였기 때문에 보다 높은 성능이 구현되었다고 보고하였다. 이렇듯, 적절한 두께의 산화 물 박막을 코팅해주는 것은 전극의 뭉침 현상을 완화하 고 전극 반응에 대한 활성점을 유지해주는 방법으로, 고 성능/고내구성 전극 개발을 위해서 많은 연구가 진행되 고 있다.

금속 재료 이외에도, perovskite계 산화물 $\left(\mathrm{ABO}_{3}\right)$ 은 고온에서 높은 전자/산소이온 전도도뿐만 아니라 높은 열적 안정성, 우수한 촉매 특성으로 인해서 귀금속 물질 을 대체할 수 있는 전극 소재로 많은 연구가 되고 있다. 하지만, 고온에 노출된 산화물 전극의 표면에서, 편석 현상, 2 차상 형성 및 원자 재배열 등의 문제로 인한 표 면에서의 전극 활성의 감소는 많은 이슈가 되고 있다. A site에 Sr이 도핑된 산화물을 예로 들어 설명하면, 고온 에 노출된 산화물 표면에 $\mathrm{Sr}$ 이 모이고, 더 나아가서 표 


\section{특 집 ㅁㅃ 서종수, 정우철', 김정환 ${ }^{2+}$}
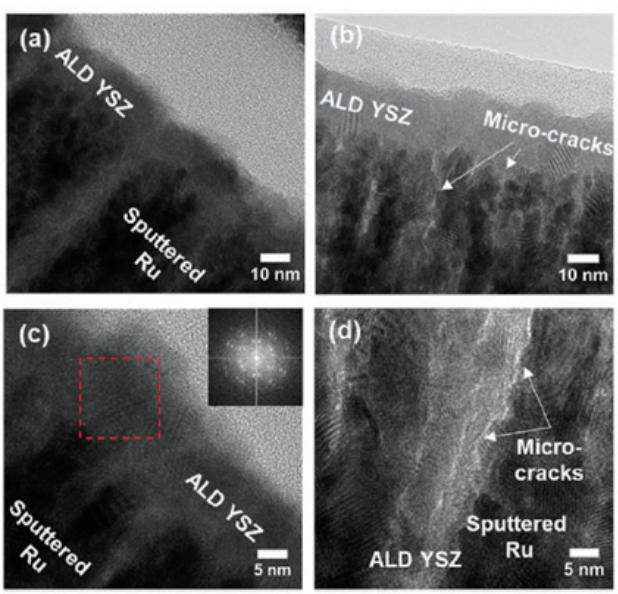

Fig. 6. $\mathrm{ALD}$ 를 이용하여 $\mathrm{YSZ}$ 가 증착된 Ru 전극의 단면 TEM 사진. ${ }^{13}$

면에서 $\mathrm{SrO}$ 와 같은 절연성의 물질을 형성하는 문제로 인해서 성능이 감소하는 현상들이 많이 보고되었다. 최 근, 이를 해결하고자 전극 표면에 $\mathrm{ALD}$ 를 이용한 산화물 코팅을 통해, 표면의 화학적 상태를 개질하여 장기 내구 성을 확보하는 연구들이 진행되고 있다. Kevin Huang 연구팀은 $\mathrm{La}_{0.6} \mathrm{Sr}_{0.4} \mathrm{CoO}_{3}$ (LSC)의 산화물 전극 표면을, $\mathrm{ALD}$ 를 이용하여 $5 \mathrm{~nm}$ 의 $\mathrm{ZrO}_{2}$ 를 코팅하면 장기 내구성 이 크게 증진된다는 것을 보고하였다 (Fig. 7).

코팅이 되지 않은 전극의 경우 $700{ }^{\circ} \mathrm{C}$ 에서 4000 시간 동안 전극 반응성을 살펴보면, $0.79 \mathrm{ohm} \cdot \mathrm{cm}^{2} \cdot \mathrm{Kh}^{-1}$ 만큼의 열화율을 보이는 반면, $\mathrm{ZrO}_{2}$ 가 코팅된 전 극의 경우는 20 배 가량 향상된 내구성, 약 0.04 $\mathrm{ohm} \cdot \mathrm{cm}^{2} \cdot \mathrm{Kh}^{-1}$ 의 열화율을 보이는 것으로 확인되었 다. 본 연구팀은, 표면에 $\mathrm{ZrO}_{2}$ 를 코팅하면, $\mathrm{ZrO}_{2}$ 내부
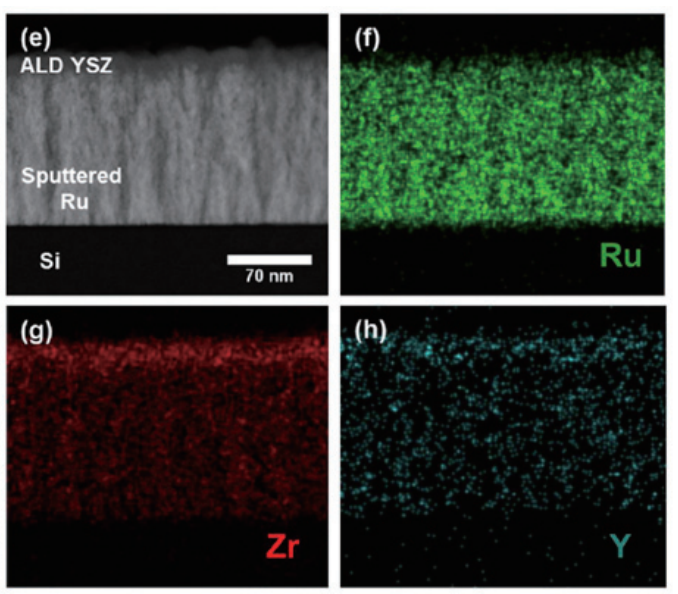

로는 $\mathrm{Co}$ 가 올라와서 음의 전하를 지니는 $\mathrm{Co}_{\mathrm{Zr}}$ 를 형성하 고, LSC 표면에서는 Zro이 Co자리로 들어가서 양의 전 하를 지니는 $\mathrm{Zr}_{\mathrm{Co}}$ 를 형성하여 space charge region을 형성한다고 주장하였다. 이로 인해서, 음의 전하를 띄고 있는 $\mathrm{Sr}_{\mathrm{La}}$ '이 charge interaction에 의해서 표면으로 올 라오는 구동력을 억제하여, 장기 내구성을 향상하였다 고 보고하였다.

최근에는, Jason D. Nicholas 연구팀은 $\mathrm{La}_{0.6} \mathrm{Sr}_{0.4}$ $\mathrm{Co}_{0.8} \mathrm{Fe}_{0.2} \mathrm{O}_{3}$ (LSCF) 산화물 전극에도 $\mathrm{ZrO}_{2}$ 를 다양한 두 께로 코팅하여 ALD 코팅이 전극 반응성에 미치는 효과 를 보고하였다 (Fig. 8). 본 연구에서는, 코팅을 하지 않 은 $\mathrm{LSCF}$ 전극의 경우는 $45 \% / \mathrm{kh}$ 의 열화율을 보인 반 면, $5 \mathrm{~nm}$ 의 $\mathrm{ZrO}_{2}$ 가 코팅된 전극의 경우에는 열화율이 $12 \% / \mathrm{kh}$ 로 성공적으로 열화 억제가 가능한 것을 확인하
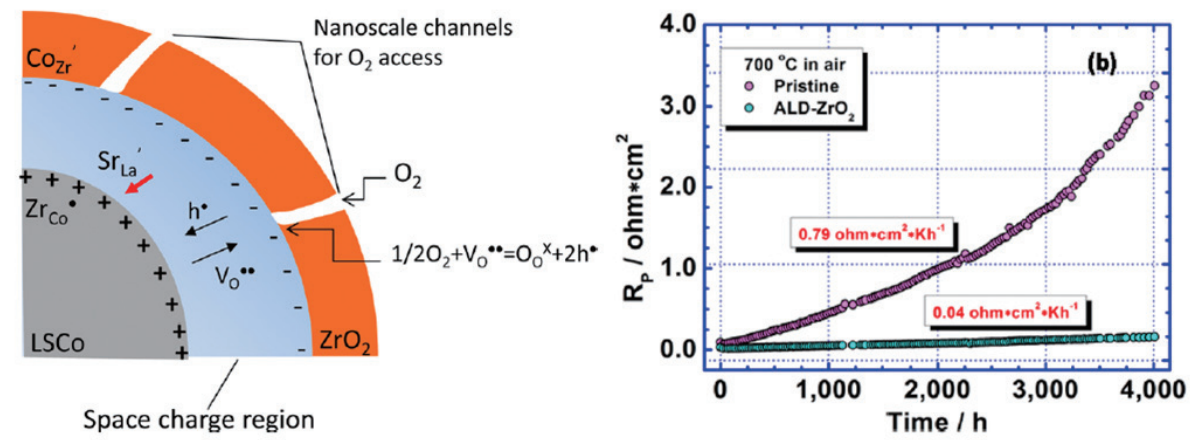

Fig. 7. $\mathrm{ZrO}_{2}$ 가 코팅된 $\mathrm{La}_{0.6} \mathrm{Sr}_{0.4} \mathrm{CoO}_{3}$ (LSC) 표면에 형성된 space charge 모식도 및 $\mathrm{ZrO}_{2}$ 코팅 유무에 따른 $\mathrm{LSC}$ 의 전극 성능 변화. ${ }^{14)}$ 


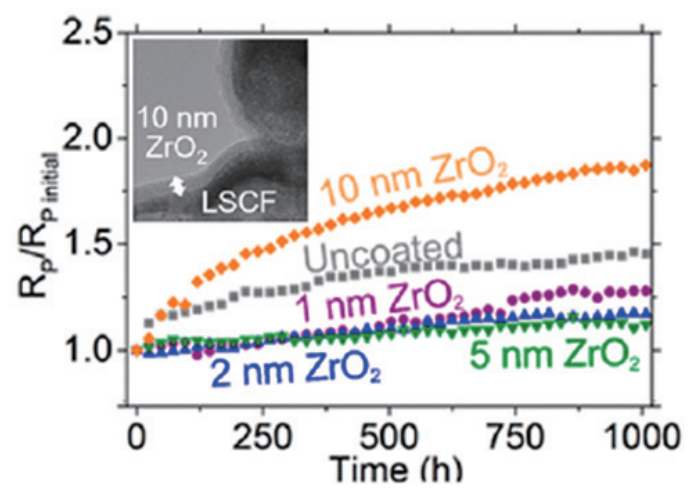

Fig. 8. $\mathrm{ZrO}_{2}$ 코팅 유무에 따른 $\mathrm{La}_{0.6} \mathrm{Sr}_{0.4} \mathrm{CO}_{0.8} \mathrm{Fe}_{0.2} \mathrm{O}_{3}$ 전극의 성능 변화.

였다. 그 이유로는, 앞선 연구에서와는 달리, 편석되는 $\mathrm{Sr}$ 의 구동력을 억제하는 것이 아니라, 편석된 $\mathrm{Sr}$ 이 표면 에 코팅된 Zr과 반응하여 $\mathrm{SrZrO}_{3}$ 를 형성하면서, $\mathrm{Sr}$ 를 clean up 하였기 때문에, 성능 열화를 억제하였다고 주 장하였다. 이처럼, $\mathrm{ALD}$ 를 통해서 성공적으로 산화물 전 극의 반응성 및 내구성 향상을 보고한 문헌들도 많이 존 재하지만, 여전히 반응 기작에 대한 정확한 mechanism 이 불분명한 상황이다. 더 나아가서, ALD 코팅이 산화 물 전극의 반응성 및 내구성 향상에 좋다는 문헌뿐만 아 니라, 그렇지 않다는 문헌들도 종종 보고가 되었다. 그 러므로 $\mathrm{ALD}$ 코팅을 통한 고성능/고내구성의 산화물 전 극 개발을 위해서, 표면 코팅이 산화물 전극에 미치는
영향에 대한 보다 체계적인 연구가 아직은 더 필요한 실 정이다.

이처럼, $\mathrm{ALD}$ 코팅을 이용한 전극의 열적/화학적 내 구성 향상뿐만 아니라, 산화물-금속 나노촉매로 이 루어진 복잡한 $\mathrm{SOFC}$ 전극에서도 $\mathrm{ALD}$ 의 도입은 고 성능의 $\mathrm{SOFC}$ 전극을 개발하는 방법임이 최근 보고되 었다. 화학 촉매 분야에서, $\mathrm{ALD}$ 를 이용하여 제작된 heterogeneous surface-coated catalysts는 높은 촉 매 활성 및 고온에서의 우수한 열적/화학적 안정성으 로 인해서 많은 application에서 활발히 연구가 진행 되고 있다. 예를 들면, $\mathrm{Pd}$ 나노입자의 경우 oxidative dehydrogenation of ethane 반응에 있어서 매우 우수 한 촉매 활성을 보이는 것으로 알려져 있으나, $\mathrm{Pd}$ 의 뭉 침 현상으로 인한 비표면적 감소 및 탄소 침적으로 인해 서 급격한 반응성 저하된다는 문제가 존재한다. 이에, Peter C. Stair 연구팀은 $\mathrm{ALD}$ 를 이용하여 $\mathrm{Al}_{2} \mathrm{O}_{3}$ 를 코 팅해주어 $\mathrm{Pd}$ 의 열적/화학적 안정성을 성공적으로 향상 할 수 있음을 보고하였다. ${ }^{16)}$ 본 연구팀에서는, $\mathrm{Pd}$ 의 안 정성이 향상되는 이유로, 고온에 노출된 $\mathrm{Al}_{2} \mathrm{O}_{3}$ 박막에 형 성된 nano-pore의 사이즈가 약 $7 \mathrm{~nm}$ 이하로 탄소가 성장하기에는 매우 작은 것뿐만 아니라, $\mathrm{Al}_{2} \mathrm{O}_{3}$ 가 $\mathrm{Pd}$ 위 에 코팅이 될 때, 탄소 침적의 활성점인 edge나 terrace site에 우선적으로 증착이 되기 때문에 $\mathrm{Pd}$ 의 안정성이 크게 증가한다고 주장하였다. 이렇듯, $\mathrm{ALD}$ 를 이용한 금
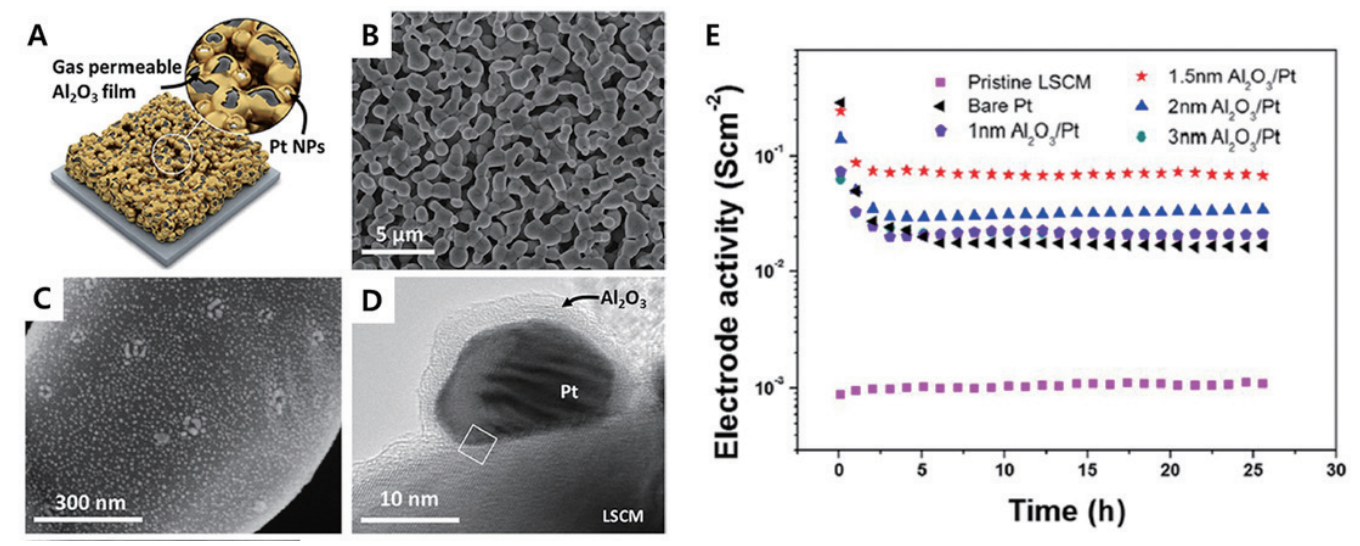

Fig. 9. (A) ALD를 이용하여 나노촉매가 담지된 SOFC 전극을 코팅하는 하는 모식도. (B) 제작된 $\mathrm{La}_{0.75} \mathrm{Sr}_{0.25} \mathrm{Cr}_{0.5} \mathrm{Mn}_{0.5} \mathrm{O}_{3}$ (LSCM) 전극 SEM 사진. (C) 나노입자가 담지된 LSCM 전극의 SEM 사진. (D) $\mathrm{Al}_{2} \mathrm{O}_{3}$ 가 코팅된 Pt-LSCM 전극의 TEM 사진. (E) $\mathrm{Al}_{2} \mathrm{O}_{3}$ 의 코팅 유무에 따 른 전극의 임피던스 분석 결과.5) 

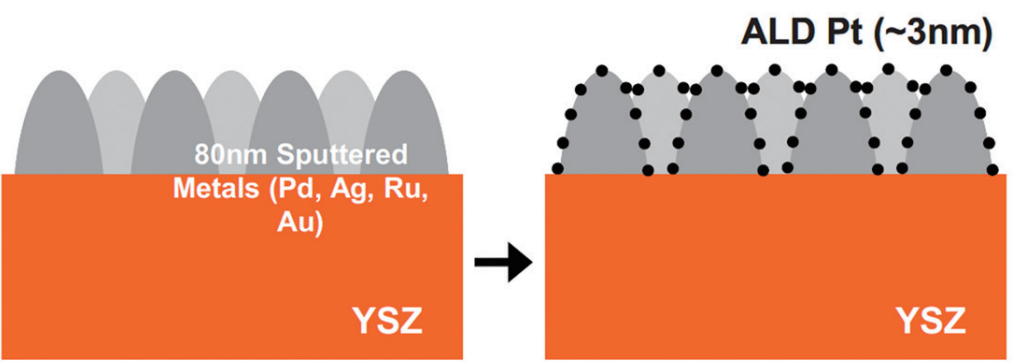

Fig. 10. ALD를 Pt 나노입자가 증착된 금속 전극의 모식도. ${ }^{17)}$

속 나노 촉매 코팅은 화학촉매 분야에서 성공적인 성능 향상을 이루어 냈으나, 고온 전기화학 촉매에는 적용된 사례가 전무하였다.

하지만, 최근 우리 연구팀은 ALD를 이용한 금속-산 화물 복합 나노 촉매 제작은 고성능/고내구성을 지니는 $\mathrm{SOFC}$ 전극을 개발할 수 있는 방법임을 확인하였다. 우 리 연구팀에서는 $\mathrm{La}_{0.75} \mathrm{Sr}_{0.25} \mathrm{Cr}_{0.5} \mathrm{Mn}_{0.5} \mathrm{O}_{3}$ (LSCM) 산화 물 전극 위에 도입된 $\mathrm{Pt}$ 나노입자를 $\mathrm{ALD}$ 를 이용하여 열 적/화학적 안정성을 효과적으로 향상하여 고성능/고내 구성의 전극 개발에 성공하였다.

Fig. 9를 보면, 용액 침투 공정을 통해 $10 \mathrm{~nm}$ 의 백 금 나노입자가 LSCM 표면에 잘 도포 된 것을 알 수 있 다. 또한, $\mathrm{TEM}$ 분석을 통해 $\mathrm{ALD}$ 를 이용한 $\mathrm{Al}_{2} \mathrm{O}_{3}$ 코팅 이 Pt 나노입자와 LSCM전극 표면에 균일하게 코팅되었 음을 확인하였다. 이렇게 제작된 전극의 임피던스의 초 기 분석 결과를 보면, $650{ }^{\circ} \mathrm{C}$ wet $\left(2 \% \mathrm{H}_{2} \mathrm{O}\right) \mathrm{CH}_{4}$ 분위 기에서, 나노입자가 없는 LSCM전극 대비 나노입자가 담지된 LSCM전극은 100 배 이상의 높은 전극 반응성을 보이는 것을 알 수 있었다. 하지만 백금 나노입자의 열 적 불안정성 및 탄소 침적 문제로 인해서 매우 빠른시간 안에 급격한 성능 감소를 보이는 것이 확인되었다. 이와 반면에, $1.5 \mathrm{~nm}$ 의 $\mathrm{Al}_{2} \mathrm{O}_{3}$ 가 코팅된 전극의 경우는, 25 시간이 지난 이후에도 bare LSCM 전극 대비 100배 이 상의 전극 활성을 유지하는 것을 확인하였다. 하지만, $\mathrm{Al}_{2} \mathrm{O}_{3}$ 를 $1.5 \mathrm{~nm}$ 보다 두껍거나, 얇게 코팅하게 되면, 활 성점을 가리거나, 탄소 침적 완화에 충분하지 않은 두께 이기 때문에 전극 성능이 감소한다고 보고하였다. 이러 한 경향성이 보이는 이유로 $\mathrm{ALD}$ 코팅 시, 백금 나노입
자의 안정성과 반응 활성점 확보 사이의 trade off 관계 로 인해 $1.5 \mathrm{~nm}$ 에서 최적점을 보이는 것이라고 주장하 였다. 본 연구는, 메탄 연료에서 고성능/고내구성의 전 극을 개발하였다는 것뿐만 아니라, ALD 기술을 도입한 다면 열적/화학적 불안정성으로 인해서 사용이 제한되 었던 금속 나노촉매를, 고온에서 구동하는 전기화학 장 치에도 활용할 수 있음을 시사하는 최초의 논문이다.

\subsection{Surface functionalization via ALD}

$\mathrm{ALD}$ 코팅을 이용하여 전극의 열적/화학적 안정성을 향상하여 전극의 활성 및 내구성을 향상하는 것뿐만 아 니라, 표면에 기능성 산화물이나 금속 나노촉매를 코팅 하여 전극의 반응성 자체를 향상시키는 연구 또한 활발 히 진행되고 있다. $\mathrm{ALD}$ 는 cycle의 순서 및 횟수 조절 을 통해서 다양한 조성의 복합 산화물을 쉽게 증착할 수 있으며, 더 나아가 다양한 금속도 증착할 수 있다는 장 점이 있다. Fritz B. Prinz 연구팀은 sputtering을 통 해 제작된 다양한 금속 전극위에, 약 $3 \mathrm{~nm}$ 가량의 $\mathrm{Pt}$ 를 $\mathrm{ALD}$ 를 통해 증착하여 전극의 물질 종류에 따른 $\mathrm{Pt}$ 의 증착 거동과, $\mathrm{ORR}$ 반응성에 미치는 효과를 보고하였다 (Fig. 10).

우선, 본 연구팀에서는 스퍼터로 제작된 전극이 지니 는 표면 에너지와 $\mathrm{ALD}$ 로 증착되는 $\mathrm{Pt}$ 와의 표면 에너지 차이를 이용하여 증착되는 $\mathrm{Pt}$ 의 형상을 설명하였다. $\mathrm{Ru}$ 의 표면에너지는 $3.4 \mathrm{~J} / \mathrm{m}^{2}$ 으로 $\mathrm{Pt}$ 가 지니는 표면에너지 인 $2.7 \mathrm{~J} / \mathrm{m}^{2}$ 에 비해서 큰 표면 에너지를 지녔기 때문에, 표면에 증착이 되면 지지체가 Core, 코팅층이 shell 구 조를 이루는 core-shell 구조를 지닌다고 주장하였다. 

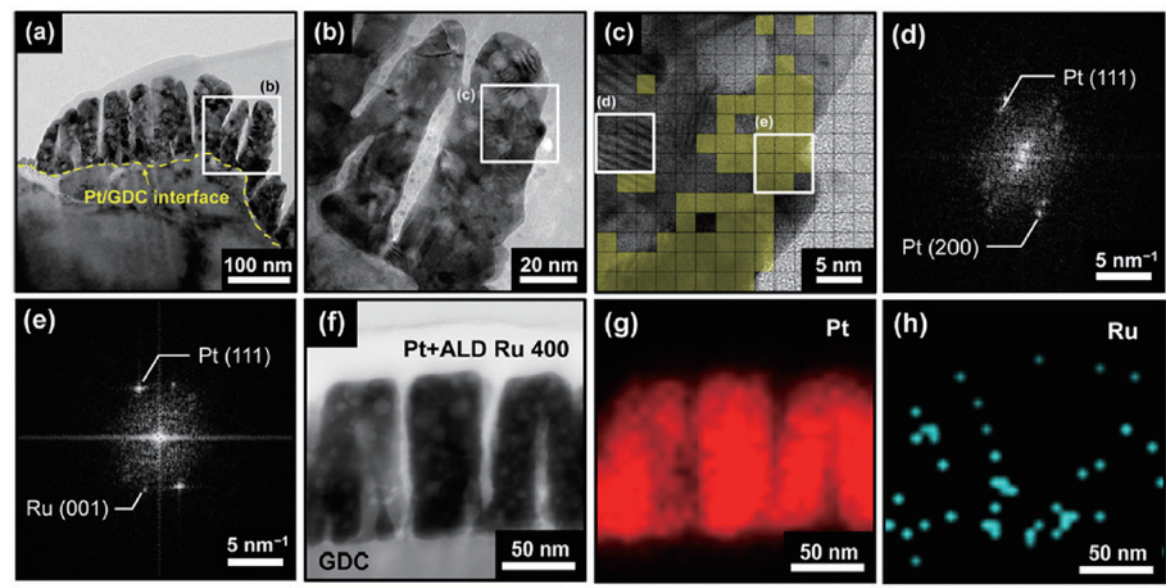

Fig. 11. ALD를 이용하여 Ru 나노촉매가 도입된 Pt 전극의 단면 TEM 사진. ${ }^{18)}$

반대의 경우 $\left(\mathrm{Ag}: 1.3 \mathrm{~J} / \mathrm{m}^{2}, \mathrm{Pd}: 2.0 \mathrm{~J} / \mathrm{m}^{2}\right)$ 에는, 증착되 는 Pt가 shell구조가 아닌, 전극 표면에서 작은 핵 형성 을 통해 island cluster를 형성한다고 주장하였다. 또한, $\mathrm{I}-\mathrm{V}$ 분석을 통해, $\mathrm{Pt}$ 촉매가 증착되지 않은 전극 대비, $\mathrm{Pt}$ 촉매가 사용된 $\mathrm{Ag}, \mathrm{Pd}, \mathrm{Ru}$ 전극 모두에서 우수한 열 적 안정성 및 성능 향상을 확인하였다. 이러한 이유로는 백금 자체의 높은 열적 안정성뿐만 아니라, 표면에서 백 금이 지지체 금속과 alloying되어 지지체의 산화를 방 지하였기 때문이라고 주장하였다. 뿐만 아니라, $\mathrm{Pt}$ 촉매 가 증착된 전극을, 스퍼터를 통해서 $80 \mathrm{~nm}$ 의 두께로 제 작된 백금 전극과 비교하였을 때, 소량의 촉매만 도입 이 되더라도 스퍼터를 통해 제작된 Pt전극과 유사한 성 능을 보이는 것을 보고하였다. 본 연구는 $\mathrm{ALD}$ 를 이용 한 촉매 도입을 통한 성공적인 ORR 반응성 향상뿐만 아 니라, 추후에 $\mathrm{ALD}$ 를 이용하여 금속 촉매를 도입할 때의 전극 디자인 설계 지표를 제시하였다는 점에서 의의를 지니는 논문이다.

ORR 반응뿐만 아니라, 심준형 교수 연구팀은 methanol oxidation 반응 촉진을 위해 $\mathrm{Ru}$ 촉매를 $\mathrm{ALD}$ 를 이용하여서 SOFC anode에 도입하였다 (Fig. 11). $\mathrm{TEM}$ 분석 결과 스퍼터링을 이용하여 제작된 백금 전극 위에 $\mathrm{ALD}$ 를 통해 증착한 $\mathrm{Ru}$ 이 island growth가 이루 어진 것을 확인하였다. 이렇게 제작된 전극의 $\mathrm{I}-\mathrm{V}$ 분석 결과, $450{ }^{\circ} \mathrm{C}$ 에서 $\mathrm{Ru}$ 이 코팅되지 않은 백금전극에 비
해, $\mathrm{Ru}$ 이 100 cycle 증착된 백금 전극의 전력 밀도가 10 배 이상 향상되는 것을 확인하였다. 또한, SEM 분석을 통해 $\mathrm{Ru}$ 이 증착되지 않은 백금 전극은, 측정 후 $\mathrm{TPB}$ 가 $75 \%$ 가량 줄어들었지만, $\mathrm{Ru}$ 이 증착된 전극의 경우 $4 \%$ 이내의 TPB 감소율을 보이는 것을 통해 효과적인 활성 점 유지를 통해 전극 성능이 향상되었다고 주장하였다. 또한, 메탄올 산화반응을 자세히 살펴보면

$$
\mathrm{CH}_{3} \mathrm{OH}+2 \mathrm{O}^{2-} \rightarrow \mathrm{CO}+2 \mathrm{H}_{2} \mathrm{O}+4 \mathrm{e}^{-}
$$

위와 같은데, $\mathrm{Pt}$ 는 일반적으로 산화반응에 있어서 매우 뛰어난 촉매로 알려져 있다. 하지만 Pt는 형성 물인 $\mathrm{CO}$ 에 의해 표면이 쉽게 poisoning되어 계속적 으로 반응에 참여하기 어렵다는 문제가 있다. 이렇게 poisoning 된 $\mathrm{CO}$ 는 다음과 같이 표면에서의 산화반응 에 의해서 제거될 수 있다고 알려져 있다.

$$
\mathrm{CO}+\mathrm{OH}^{-} \rightarrow \mathrm{CO}_{2}+\mathrm{H}^{+}+2 \mathrm{e}^{-}
$$

이때, 표면에서의 $\mathrm{OH}^{-}$는 연료 주입 시에 공급되는 물 의 dehydrogenation 반응으로 인해서 공급될 수 있다.

$$
\mathrm{H}_{2} \mathrm{O} \rightarrow \mathrm{OH}^{-}+\mathrm{H}^{+}
$$




\section{특 집}

A

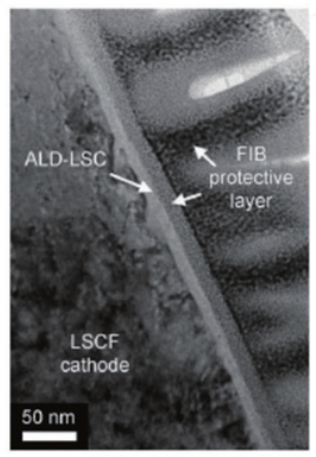

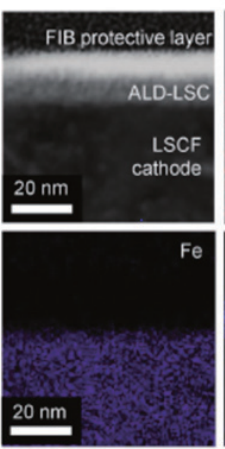

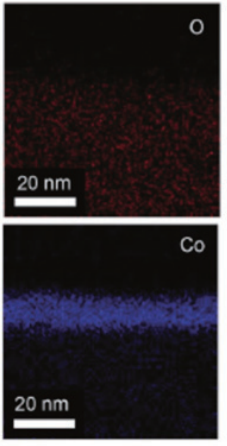

B

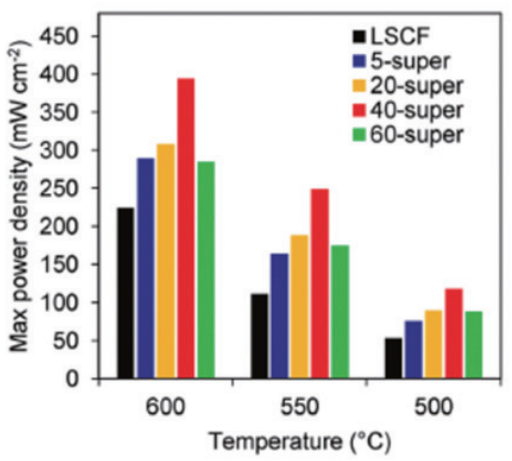

Fig. 12. (A) $\mathrm{ALD}$ 를 이용하여 $\mathrm{La}_{0.6} \mathrm{Sr}_{0.4} \mathrm{Co}_{0.2} \mathrm{Fe}_{0.8} \mathrm{O}_{3}$ (LSCF) 전극에 코팅된 $\mathrm{La}_{0.55} \mathrm{Sr}_{0.4} \mathrm{CoO}_{3}$ (LSC)의 단면 $\mathrm{TEM}$ 사진. (B) $\mathrm{LSC}$ 코팅 유무에 따른 전력 밀도.

위 반응에 있어서 $\mathrm{Ru}$ 이 $\mathrm{Pt}$ 보다 우수한 촉매로 작용 하기 때문에, $\mathrm{Ru}$ 도입을 통해 효율적으로 $\mathrm{OH}^{-}$를 공급 해줄 수 있게 된다. 그러므로, 본 연구팀은 $\mathrm{Ru}$ 의 도입 을 통해 $\mathrm{Pt}$ 의 열적 안정성 확보뿐만 아니라, 백금의 $\mathrm{CO}$ poisoning을 효과적으로 억제해줌으로써 고성능/고내 구성의 전극을 구현할 수 있다고 보고하였다.

이렇게 금속 촉매의 도입뿐만 아니라 심준형 교수 연구팀은 복잡한 조성을 지니는 기능성 산화물 코팅 을 통해 표면에서의 ORR 반응의 극대화에 성공하였다 (Fig. 12).

본 연구팀은 $\mathrm{SrO} / \mathrm{CoO}_{\mathrm{x}} / \mathrm{La}_{2} \mathrm{O}_{3}$ 로 이루어진 $\mathrm{ALD}$ cycle을 반복하여 $\mathrm{La}_{0.57} \mathrm{Sr}_{0.4} \mathrm{CoO}_{3}$ (LSC) 산화물 증착에 성공하였다. TEM분석을 통해 pulse layer deposition (PLD) 기법을 이용하여 제작된 다공성의 나노 구조체를 지니는 $\mathrm{La}_{0,6} \mathrm{Sr}_{0.4} \mathrm{Co}_{0.2} \mathrm{Fe}_{0.8} \mathrm{O}_{3}$ (LSCF) 전극 위에도 $\mathrm{LSC}$ 가 균일하게 코팅되는 것을 확인하였다. 또한, XRD 및 $\mathrm{TEM}$ 분석을 통해 증착된 LSC는 amorphous한 결정 구조 안에 부분적으로 결정화가 되어있는 형태로 증착 이 된다는 것을 확인하였다. I-V 분석을 통해서, 코팅이 되지 않은 전극에 비해 LSC가 코팅된 셀의 성능이 600 ${ }^{\circ} \mathrm{C}$ 에서 최대 2 배가량 향상된다는 것을 보고하였다. 이는 $\mathrm{LSCF}$ 보다 LSC가 ORR반응에 있어서 보다 촉매 활성이 높기 때문이라고 주장하고 있다. 뿐만 아니라 본 연구에 서는, DFT결과를 통해서 $\mathrm{ALD}$ 로 제작된 $\mathrm{LSC}$ 는 소량의
결정질이 포함된 비결정질의 $\mathrm{LSC}$ 로써, 결정을 이루고 있는 LSC에 비해 ORR 반응에 있어서 활성이 우수함을 제시하고 있다. 이는 성공적인 ORR 반응성 향상뿐만 아 니라, $\mathrm{ALD}$ 를 이용하여 제작하는 복잡한 조성의 박막이 지니는 특이한 결정성에 대한 특성을 보고한 내용으로, 추후에 $\mathrm{ALD}$ 를 이용한 다양한 조성의 박막 코팅 도입은 기존의 방식과는 다른 고성능의 $\mathrm{SOFC}$ 전극을 제작이 가능한 기술임을 시사하는 데 의의가 있는 보고이다.

\section{Future SOFC applications of ALD}

$\mathrm{ALD}$ 는 $\mathrm{ALD}$ 가 지닌 다양한 장점을 이용하여 $\mathrm{SOFC}$ 의 전해질 및 전극이 겪고 있는 다양한 문제들을 효과적으 로 해결할 수 있었다. $\mathrm{SOFC}$ 분야로의 $\mathrm{ALD}$ 도입은, 전해 질 제작뿐만 아니라, 전극 및 나노 촉매의 안정화, 더 나 아가 금속 촉매 및 다성분계의 기능성 산화물 코팅을 통 해 고성능/고내구성 $\mathrm{SOFC}$ 전극을 개발하는 새로운 연 구 분야를 열어 주었다. 괄목할만한 성과로는 다성분계 산화물 코팅을 통해 $\mathrm{SOFC}$ 전극의 반응 활성을 극대화할 수 있다는 점이다. $\mathrm{ALD}$ 는 증착하고자 하는 precursor 와 reactant pulse 조절을 통해 손쉽게 박막의 조성을 조절할 수 있다. 그러므로 $\mathrm{ALD}$ 를 이용하여 다양한 조성 의 기능성 산화물 코팅이 $\mathrm{SOFC}$ 전극의 반응성에 미치 는 효과에 관한 다양한 연구가 이루어진다면 고성능/고 내구성의 $\mathrm{SOFC}$ 전극 개발이 가능할 것이다. 뿐만 아니 
라 금속 나노입자가 담지 된 $\mathrm{SOFC}$ 전극에 $\mathrm{ALD}$ 의 도입 은 고활성의 금속 나노 촉매를 $\mathrm{SOFC}$ 전극에 적용 가능 하게 해줄 수 있다. 그러므로 앞에서 말한 다성분계 산 화물 코팅을 금속 나노촉매가 담지된 전극에 도입한다면 $\mathrm{Al}_{2} \mathrm{O}_{3}$ 를 코팅하였을 때 보다 우수한 성능 향상을 기대 할 수 있을 것이다. 또한, 다양한 코팅 물질 탐색 및 도 입을 통해, $\mathrm{ALD}$ 코팅층과 금속 나노입자 사이의 strong metal support interaction 으로 인한 흥미로운 현상들 도 $\mathrm{SOFC}$ 전극 표면에서 구현할 수 있을 것이다.

\section{Conclusion}

본 리뷰에서, $\mathrm{ALD}$ 가 $\mathrm{SOFC}$ 의 전해질, 전극 제작에 도입되어 이루어낸 성공적인 사례들에 대해서 살펴보았 다. 얇고, 치밀한 박막을 제공할 수 있는 $\mathrm{ALD}$ 를 이용하 여 제작된 전해질은 $\mathrm{SOFC}$ 의 ohmic loss를 최소화하여 전력 밀도를 크게 향상시켰다. 또한, 우수한 단차피복성 이 장점인 $\mathrm{ALD}$ 를 이용하여 복잡한 3-D 구조체를 지니 는 $\mathrm{SOFC}$ 전극 표면에 다양한 산화물 및 금속 촉매를 균 일하게 코팅함으로써 $\mathrm{SOFC}$ 전극의 성공적인 안정화/ 기능화에 성공하였다. 이렇게 성공적인 성능 향상들이 많이 보고되었지만, $\mathrm{ALD}$ 가 전극의 반응성이나 내구성 에 미치는 정확한 메커니즘에 관한 추가적인 연구가 필 요한 상황이다. $\mathrm{ALD}$ 기술 적용에 대한 보다 체계적인 연구를 통해 고성능/고내구성의 전해질 및 전극 구현과 $\mathrm{SOFC}$ 분야의 새로운 도약을 기대해 본다.

\section{REFERENCES}

(1) Park T. J., Kim J. H., Jang J. H., Lee C.-K., Na K. D., Lee S. Y., Jung H.-S., Kim M., Han S., Hwang C. S., "Reduction of electrical defects in atomic layer deposited $\mathrm{HfO}_{2}$ films by Al doping," Chem. Mater., 22 [14] 4175-4184 (2010).

(2) Kim S. K., Choi G. J., Kim J. H., Hwang C. S, "Growth behavior of $\mathrm{Al}$-doped $\mathrm{TiO}_{2}$ thin films by atomic layer deposition," Chem. Mater., 20 [11] 3723-3727 (2008).

(3) Yu D., Yang Y.-Q., Chen, Z., Tao Y., Liu Y.-F., "Recent progress on thin-film encapsulation technologies for organic electronic devices," Opt. Commun., 362, 43-49 (2016).

(4) Meng X., Wang X. Geng, D., Ozgit-Akgun C., Schneider N., Elam, J. W, "Atomic layer deposition for nanomaterial synthesis and functionalization in energy technology," Mater. Horiz., 4 [2] 133-154 (2017).

(5) Seo J., Tsvetkov N., Jeong S. J., Yoo Y., Ji S., Kim J. H., Kang J. K., Jung W. J., "Interfaces, Gas Permeable Inorganic Shell Improves the Coking Stability and Electrochemical Reactivity of Pt towards Methane Oxidation," ACS Appl. Mater. Interfaces., 12 4405-4413 (2020)

(6) Ylilammi M. J., "Monolayer thickness in atomic layer deposition," Thin Solid Films., 279 [1-2] 124-130 (1996).

(7) Puurunen, R. L., "Surface chemistry of atomic layer deposition: A case study for the trimethylaluminum/water process," J. Appl. Phys., 97 [12] 9 (2005).

(8) Gordon R. G., Hausmann D., Kim, E., Shepard, J., "A kinetic model for step coverage by atomic layer deposition in narrow holes or trenches," Chem. Vap. Depos., 9 [2] 73-78 (2003).

(9) Kim J. H., Park T. J., Kim S. K., Cho D. - Y., Jung H. - S., Lee S. Y., Hwang, C. S., "Chemical structures and electrical properties of atomic layer deposited $\mathrm{HfO}_{2}$ thin films grown at an extremely low temperature $(\leq 100$ $\left.{ }^{\circ} \mathrm{C}\right)$ using $\mathrm{O}_{3}$ as an oxygen source," Appl. Surf. Sci., 292 852-856 (2014).

(10) Shim J. H., Chao C. -C., Huang H., Prinz, F., "Atomic layer deposition of yttria-stabilized zirconia for solid oxide fuel cells," Chem. Mater., 19 [15] 3850-3854 (2007).

(11) Fan Z., Chao C.-C., Hossein-Babaei F., Prinz, F., "Improving solid oxide fuel cells with yttria-doped ceria interlayers by atomic layer deposition," J. Mater. Chem., 21 [29] 10903-10906 (2011).

(12) Seo H. G., Ji S., Seo J., Kim S., Koo B., Choi Y., Kim H., Kim J. H., Kim, T.-S., Jung W., "Compounds, Sintering-resistant platinum electrode achieved through atomic layer deposition for thin-film solid oxide fuel cells," 
J. Alloy. Compd., 155347 (2020).

(13) Go D., Yang B. C., Shin J. W., Kim H. J., Lee S., Kye S., Kim, S., An, J., "Atomic layer deposited YSZ overlayer on $\mathrm{Ru}$ for direct methane utilization in solid oxide fuel cell," Ceram. Int., 46 [2] 1705-1710 (2020).

(14) Gong Y., Palacio D., Song X., Patel R. L., Liang X., Zhao X., Goodenough J. B., Huang K. J., "Stabilizing nanostructured solid oxide fuel cell cathode with atomic layer deposition," Nano Lett., 13 [9] 4340-4345 (2013).

(15) Zhang Y., Wen Y., Huang K., Nicholas J., "Atomic Layer Deposited Zirconia Overcoats as On-Board Strontium Getters for Improved Solid Oxide Fuel Cell Nanocomposite Cathode Durability," ACS Appl. Energy Mater., 3 [4], 4057-4067 (2020).

(16) Lu J., Fu B., Kung M. C., Xiao G., Elam J. W., Kung H. H., Stair, P., "Coking-
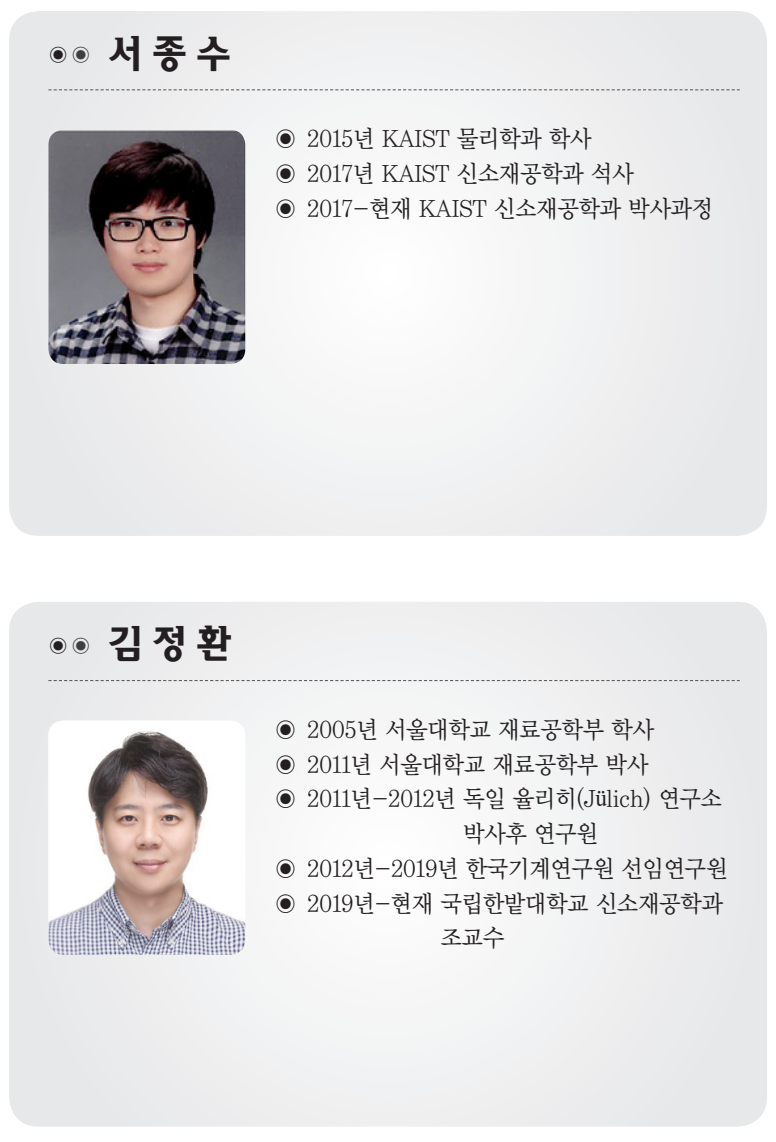

and sintering-resistant palladium catalysts achieved through atomic layer deposition," Science, 335 [6073] 1205-1208 (2012).

(17) Shim J. H., Jiang X., Bent S. F., Prinz F. "Catalysts with Pt surface coating by atomic layer deposition for solid oxide fuel cells," $J$. Electrochm. Soc., 157 [6] B793-B797 (2010).

(18) Jeong H. J., Kim J. W., Bae K., Jung H., Shim J., "Platinum - ruthenium heterogeneous catalytic anodes prepared by atomic layer deposition for use in direct methanol solid oxide fuel cells," ACS Catal., 5 [3] 1914-1921 (2015).

(19) Choi H. J., Bae K., Grieshammer S., Han G. D., Park S. W., Kim J. W., Jang, D. Y., Koo J., Son J. W., Martin M., "Surface tuning of solid oxide fuel cell cathode by atomic layer deposition," Adv. Energy. Mater., 8 [33] 1802506 (2018).

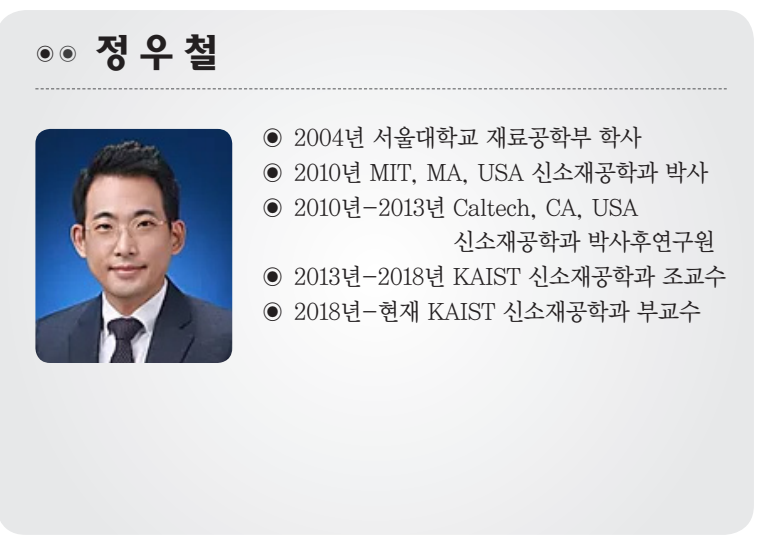

